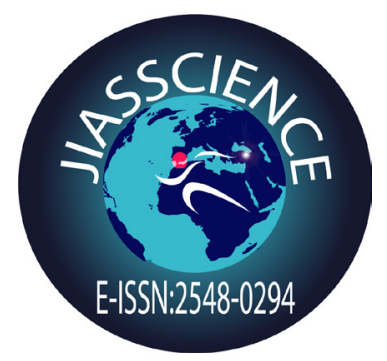

RefNum
Manuscript Category
Manuscript Type
Received
Accepted
Corresponding Author

JIASS-92486

Psycho-Social Fields in Sports

Original Research

23.07.2019

29.08.2019

Burkav Cevahircioğlu [burkaycevahircioglu@hotmail.com] / https://orcid.org/0000-0001-6281-9079

\title{
THE EXAMINATION OF PRE-COMPETITION ANXIETY LEVELS OF MUAY-THAI ATHLETES
}

\author{
Burkay Cevahircioğlu (D) Hacı Ali Çakıcı (D) Murat Durgutluoğlu \\ ${ }^{1}$ Ordu University, School Of Physical Education And Sport, Ordu, Turkey.
}

\begin{abstract}
The aim of this study was to examine examination of pre-competition anxiety levels of muaythai athletes. The investigation grup was composed from 350 muay-thai athletes ( 320 male and 30 female) joining to Turkey interuniversity muay-thai championship in 2018-2019 season. The demographic information form and Spielberger State-Trait Anxiety Inventory developed by Spielberger et al.(1970) and adapted to Turkish language by Oner and La Comte (1983) were used as data collection tools for measuring stated-trait anxiety levels of athletes. According to analyze results, there was no significant difference in pre-competition state-trait anxiety levels of athletes in terms of age and weight variables but there was statistically significant difference among pre-competition state-trait anxiety levels of athletes in terms of sport age variable $(p<0.05)$. Consequently, it might be said that the statetrait anxiety levels of athletes with higher sports age were lower and athletes with high sport experience were more successful in dealing with anxiety.
\end{abstract}

Key words: Anxiety, Athlete, Muay-thai, Sport, Statetrait anxiety.

\section{INTRODUCTION}

Today, it is a widely known fact that physical excellence alone is not enough to maximize sporting performance. High physical and psychological capacity prior to a competition is plays a key role in the success of athletes experiencing emotional change. Therefore, psychology focuses on sports and athletes as well as on other fields. Sport psychology not only deals with the mental states of athletes but also seeks ways to maximize their performance by analyzing their moods during training and competitions (Kuru, 2000).

Performance in sports is affected by numerous factors, one of which is anxiety. Anxiety is a feeling of unease, such as worry or fear, that one feels, without knowing exactly why, when one perceives a situation as dangerous or unsettling (Özgül, 2003). Athletes feel anxiety before competitions or when having to leave their families. Adolescents feel anxiety when they start college. Adults feel anxiety about health problems or death (Şirin \& Bayraktar, 2006).

According to Arkonaç (1993), anxiety is a state of uneasiness or state of living in unknown fear about an unknown danger or imminent misfortune. Anxiety can be defined in general 
as complex impulse from within. According to Cüceloğlu (1994), anxiety is one's effort that exceeds one's physical and psychological limits to fight the negative conditions around.

Emerging before or during any event that causes a feeling of danger, state anxiety depends on legitimate reasons that are conceived by other people as well (Öğüt, 2000). Konter (1996) argues that state anxiety might have an enabling or disabling effect on the physical, mental, mental and social potential of athletes. On the other hand, Öner and Le Compte (1995) defines state anxiety as a transient form of anxiety that often arises due to environmental stressors, the reasons for which are known to other people as well.

Anxiety plays a key role in the performance of athletes because it can have a negative effect on performance and scores (Başer, 1998). No matter how well athletes demonstrate their physical skills during competitions, the ability to cope with anxiety matters a lot. Anxiety may negatively affect athletes' decision-making skills during competitions. The higher the anxiety, the worse the athlete is at making decisions and exhibiting his/ her skills. Athletes under pressure may sometimes act wrong (Gümüş, 2002).

The aim of this study is to investigate the state anxiety levels of Muay Thai athletes.

\section{METHODS}

\section{Study Group}

The study population consisted of 500 athletes participating in the Turkish InterUniversity Muay Thai Championship. The study sample consisted of 350 athletes that participated in the Turkish Inter-University Muay Thai Championship held in Antalya in 2018.

\section{Data Collection}

Data were collected in 2018. The researchers replicated the scales and made them ready for application. They then contacted the athletes' coaches and informed them about the research and obtained permission for the research. Athletes were informed about the purpose, procedure and confidentiality of the study and that participation was voluntary. Participants completed the scales before competitions.

\section{Personal Information Form}

A personal information form consisting of questions about age, duration of sports engagement and weight class were used to determine participants' personal characteristics and independent variables.

\section{Spielberger's State-Trait Anxiety Inventory}

The State-Trait Anxiety Inventory (STAI) was developed by Spielberger et al. (1970) and adapted to Turkish language by Öner and Le Comte (1983). The STAI consists of 20 items (10 direct and 10 indirect statements) scored on a 4-point Likert scale ranging from " $1=$ never" to " $4=$ almost always," the lowest score being 20 and the highest score being 80 . Higher scores indicate greater anxiety. Öner analyzed the validity and reliability of the STAI at different times and applications and reported the correlation between the STAI scores to be significant (0.62). Öner and Le Compte found the Alpha coefficient of the scale to be 0.76 . The STAI reliability coefficients were determined using alpha correlations, which is an improved version of Kuder - Richardson 20 equation. The STAI reliability coefficients range from 0.94 to 0.96 . The item reliability and test-retest reliability correlations of the scale range from 0.43 to 0.85 and from 0.26 to 0.68 , respectively (Öner \& Le Compte, 1983).

Data Analysis

Data were analyzed using the Statistical Package for Social Sciences (SPSS version 20, Chicago, USA) at a significance level of 0.05 . Age, duration of sports engagement and weight class were independent variables. Table 1 shows the participants' demographic characteristics. Kolmogorov-Smirnov test was used to determine whether the data met the assumptions for parametric tests. Data were not normally distributed, and therefore, nonparametric tests were used. Kruskal Wallis-H was used to determine whether participants' STAI scores differed by age, duration of sports engagement and weight class. Bonferroni corrected Mann Whitney-U test was used for pairwise comparisons. 


\section{RESULTS}

Table 1. Participants' Demographic Characteristics

\begin{tabular}{|c|c|c|c|}
\hline & & $\mathbf{n}$ & $\%$ \\
\hline \multirow{3}{*}{ Age (Year) } & $\leq 20$ & 121 & 34.6 \\
\hline & $21-23$ & 139 & 39.7 \\
\hline & $\geq 24$ & 90 & 25.7 \\
\hline \multirow{4}{*}{$\begin{array}{c}\text { Duration of Sports Engagement } \\
\text { (Year) }\end{array}$} & $\leq 3$ & 114 & 32.6 \\
\hline & $3-5$ & 94 & 26.9 \\
\hline & $5-7$ & 73 & 20.9 \\
\hline & $\geq 7$ & 69 & 19.7 \\
\hline \multirow{4}{*}{ Weight Class } & Feather & 98 & 28.0 \\
\hline & Middle & 197 & 56.3 \\
\hline & Heavy & 55 & 15.7 \\
\hline & Total & 350 & 100.0 \\
\hline
\end{tabular}

$121(34.6 \%)$ participants were 20 years of age or younger, $139(39.7 \%)$ between the ages of 21 and 23 years, and $90(25.7 \%) 24$ years of age or older. $114(32.6 \%)$ participants had been actively engaged in sports for 3 years or less, 94 (26.9\%) for 3 to 5 years, 73 (20.9\%) for 5 to 7 years, and 69 $(19.7 \%)$ for 7 years or more. 98 (28.0\%) participants were featherweight, 197 (56.3\%) middleweight and $55(15.7 \%)$ heavyweight.

Table 2. Kruskal-Wallis H-Test Results Regarding Differences in STAI Scores by Age

\begin{tabular}{ccccccc} 
Age & $\mathbf{n}$ & Mean & SD & Median & IQR & P \\
\cline { 1 - 5 }$\leq 20$ & 121 & 42.55 & 7.08 & 43.00 & 12.00 & \\
\cline { 1 - 5 } $21-23$ & 139 & 40.62 & 7.24 & 40.00 & 11.00 & \multirow{2}{*}{0.102} \\
\cline { 1 - 5 }$\geq 24$ & 90 & 40.70 & 7.00 & 39.00 & 11.25 &
\end{tabular}

Table 2 shows the Kruskal Wallis H-test results regarding differences in participants' STAI scores by age. Participants' total STAI scores did not significantly differ by age ( $p>0.05)$.

Table 3. Kruskal-Wallis H-Test Results Regarding Differences in STAI Scores by Duration of Sports Engagement

\begin{tabular}{|c|c|c|c|c|c|c|c|}
\hline $\begin{array}{l}\text { Duration of Sports } \\
\text { Engagement (Year) }\end{array}$ & $\mathbf{n}$ & Mean & SD & Median & IQR & $\mathbf{P}$ & Significance \\
\hline$\leq 3$ & 114 & 42.83 & 6.87 & 43.00 & 12.00 & \multirow{4}{*}{0.001} & \multirow{4}{*}{$\begin{array}{l}\leq 3 \text { years }-5-7 \text { years } \\
\leq 3 \text { years }-\geq 7 \text { years } \\
3-5 \text { years }-\geq 7 \text { years }\end{array}$} \\
\hline $3-5$ & 94 & 41.89 & 7.07 & 41.00 & 10.25 & & \\
\hline $5-7$ & 73 & 40.41 & 6.76 & 40.00 & 11.00 & & \\
\hline$\geq 7$ & 69 & 38.95 & 7.56 & 37.00 & 10.00 & & \\
\hline
\end{tabular}

Table 3 shows the Kruskal Wallis H-test results regarding differences in participants' STAI scores by duration of sports engagement. According to the Bonferroni corrected Mann Whitney-U pairwise comparisons, participants engaged in sports for 3 years and less had significantly higher STAI scores than those engaged in sports for 5 to 7 years and 7 years or more. Moreover, participants engaged in sports for 3 to 5 years had significantly higher STAI scores than those engaged in sports for 7 years or more $(\mathrm{p}<0.05)$. 
Table 4. Kruskal-Wallis H-Test Results Regarding Differences in STAI Scores by Weight Class

\begin{tabular}{ccccccc} 
Weight Class & n & Mean & SD & Median & IQR & P \\
\cline { 1 - 5 } Feather & 98 & 41.51 & 7.04 & 41.00 & 12.00 & \\
\cline { 1 - 5 } Middle & 197 & 41.13 & 7.08 & 41.00 & 12.00 & \multirow{2}{*}{0.919} \\
\cline { 1 - 5 } Heavy & 55 & 41.58 & 7.77 & 40.00 & 10.00 &
\end{tabular}

Table 4 shows the Kruskal Wallis H-test results regarding differences in participants' STAI scores by weight class. Participants' total STAI scores did not significantly differ by weight class $(\mathrm{p}>0.05)$.

\section{DISCUSSION AND CONCLUSION}

Participants' pre-competition STAI scores did not significantly differ by age $(\mathrm{p}>0.05)$. Muay Thai athletes start sport at an early age, and therefore, have more experience in the competitive aspect of the sport, which might account for why their scores did not differ by age. Our result is similar to those reported by studies on taekwondo players (Yücel, 2003), basketball players (Erbaş \& Küçük, 2012), individual and team athletes (Civan et al. 2010), first-time divers (Oktay \& Y1ldiz, 2018) and folk dance teams (Uslu, 2018). Çelik (2010) and Hacıcaferoğlu et al. (2015), on the other hand, reported that age is negatively correlated with state anxiety. This might be due to the fact that with age comes maturity and experience, resulting in a decrease in anxiety.

According to Table 3, participants engaged in sports for 3 years and less had significantly higher pre-competition STAI scores than those engaged in sports for 5 to 7 years and 7 years or more while participants engaged in sports for 3 to 5 years had significantly higher pre-competition STAI scores than those engaged in sports for 7 years or more $(p<0.05)$. These results show that the longer the participants are engaged in Muay Thai, the less anxiety they have, which might be due to the fact that having more experience decreases their anxiety and provides them with a more relaxed mood before competitions. This result is similar to those reported by studies on professional football players (Koç, 2004), athletes (Başaran, 2008), judokas (Çelik, 2010) and folk dancers (Hacıcaferoğlu et al., 2015; Uslu, 2018).

However, some other studies on athletes (Turkmen et al., 2013), wrestlers (Özbay, 2012), elite athletes (Engür, 2002) and basketball players (Erbaş \& Küçük, 2012) reported that duration of sports engagement has no effect on anxiety. This may be because experience is less relevant to some sport branches than to others.

Participants' pre-competition STAI scores did not significantly differ by weight class (Table 4; $p>0.05$ ), indicating that weight class has no effect on Muay Thai athletes' state anxiety levels. However, no research has been conducted so far on the effect of weight class on athletes' state anxiety levels. We, therefore, cannot make any comparative analysis or draw any direct conclusions.

In conclusion, Muay Thai athletes' state anxiety levels did not differ by age and weight class but differed by duration of sports engagement. This indicates that competitions and training provide Muay Thai athletes with experience, which reduces their anxiety.

\section{REFERENCES}

Arkonaç, S. A. (1993) Psikoloji: Zihin süreçleri bilimi. Alfa Yayınları.

Başaran M.H. (2008) Sporcularda durumluk ve sürekli kaygı düzeylerinin bazı değişkenlere göre incelenmesi. Yüksek lisans Tezi, Selçuk Üniversitesi, Konya.

Başer, E. (1998) Uygulamaları spor psikolojisi. Ankara: Bağırgan Yayımevi.

Civan, A., Arı, R., Görücü, A., Özdemir, M. (2010) Bireysel ve takım sporcularının müsabaka öncesi ve sonrası durumluk ve sürekli kaygı düzeylerinin karşılaştırılması. Uluslararası İnsan Bilimleri Dergisi, 7(1), 193-206.

Cüceloğlu, D. (1994) İnsan ve davranış psikolojinin temel kavramları. İstanbul: Remzi Kitabevi.

Çelik G. (2010) Üst düzeydeki judocularda müsabaka öncesi durumluk kayg1 düzeylerinin değerlendirilmesi. Yüksek lisans tezi, Dumlupınar Üniversitesi, Kütahya. 
Engür, M. (2002) Elit sporcularda başarı motivasyonun, durumluk kayg1 düzeyleri üzerine etkisi. Yüksek lisans tezi, Ege Üniversitesi, İzmir.

Erbaş, M. K. ve Küçük, V. (2012) Üst düzey basketbolcularda durumluk kayg1 düzeylerinin farklı değişkenlere göre karşılaştırılması. Selçuk Üniversitesi Beden Eğitimi ve Spor Bilim Dergisi, 14(2), 257-261.

Gümüş, M. (2002) Profesyonel futbol takımlarında puan sıralamasına göre durumluluk kaygı düzeylerinin incelenmesi. Yayınlanmamış yüksek lisans tezi, Sakarya Üniversitesi, Sosyal Bilimler Enstitüsü, Sakarya .

Hacıcaferoğlu, S.,Hacıcaferoğlu, B., Seçer, M. (2015) Halk oyunları branşına katılan sporcuların yarışma öncesi kaygı düzeylerinin bazı değişkenler açısından incelenmesi. International Journal of Science Culture and Sport, 3 (Special Issue 4), 288-297.

Konter, E. (1996) Spor psikolojisi ve futbol. İstanbul: Saray Tıp Kitapevleri.

Kuru, E. (2000) Sporda psikoloji. Ankara: GÜ İletişim Fakültesi Basımevi.

Oktay, M. C. ve Yıldız, M. (2018) İlk defa deneme dalışı yapan bireylerin sürekli ve durumluk kaygı düzeylerinin çeşitli değişkenlere göre incelenmesi. Kafkas Üniversitesi Sosyal Bilimler Enstitüsü Dergisi, (21), 161-168.

Öner, N., Lecompte, A. (1983) Süreksiz durumluk / sürekli kaygı envanteri el kitabı. İstanbul: Boğaziçi Üniversitesi.

Özbay, S. (2012) Büyükler güreş milli takımında yer alan sporcuların, müsabaka öncesi ve sonrası durumluk kaygı düzeylerinin karşılaştırılması. Yüksek lisans tezi, Karamanoğlu Mehmet Bey Üniversitesi, Karaman.

Özgül, F. (2003) Beden eğitimi ve spor yüksekokulu öğrencilerinde durumluk ve sürekli kaygı düzeyleri, Yüksek lisans tezi, Cumhuriyet Üniversitesi, Sivas.

Spielberger, C. D.,Gorsuch, R. L., \& Lushene, R. D. (1970) STAI manual (palo alto, california, consulting psychologists press).

Şirin, E. F., Bayraktar, G. (2006) Bayan güreşçilerin umutsuzluk ve kayg1 düzeylerinin müsabaka başarılarına olan etkisinin araştırılması. Beden Eğitimi ve Spor Bilimleri Dergisi 8(3).

Türkmen, M., Kul, M., Bozkuş, T. (2013) Takım sporlarıyla uğraşan sporcuların yarışma kaygı düzeylerinin cinsiyete ve spor deneyimine göre incelenmesi. Uluslararası Hakemli Akademik Spor Sağlık ve Tıp Bilimleri Dergisi, (07), 106-112.

Uslu M.S. (2018) Halk oyuncularının yarışma öncesi durumluk kaygı düzeyleri ve stresle başa çıkma yöntemleri arasındaki ilişki. Yüksek lisans tezi, Hitit Üniversitesi, Çorum.

Yücel, E. O. (2003) Taekwondocuların durumluk ve sürekli kaygı düzeyleri ve müsabaka başarılarına etkisi. Yüksek lisans tezi, Gazi Üniversitesi, Ankara. 